\title{
Peculiarities of the Lithuanian Banking Sector Development and their Influence on Residents' Economic Security
}

The article analyses the attitudes of the population towards Lithuanian banking and public confidence in the sector regarded as an integral part of economic security. The statement that historically erroneous policies and practices are key to the present-day low public confidence in the banking sector is illustrated by factual samples of Lithuania's banking experience. The author's views are based on her previous work experience heading the Vilniaus Bankas Market Research and Marketing divisions, and are explicated on the opportunities exploited by this bank in the context of developing the banking sector. Based on a number of publications, as well as legal and statistical information, the article argues that individual opinions about financial institutions are important to the cognition of national security as a whole.

\section{Introduction}

Among the principal requirements for a successful transition from a centralised to a planned economy is the build-up of an effective financial sector. Compared to the EU member countries, where the total assets of financial intermediaries constitute $36 \%$ of GDP, with the lowest indicator of $180 \%$ in Finland, and the highest of $520 \%$ in Holland ${ }^{1}$, the Lithuanian financial sector is comparatively small and will face challenges coming from E-business and trade. It must also fill in the gaps related to EU banking safety requirements that appear with new forms of business and globalisation. In terms of the GDP share produced by Lithuanian financial institutions, banks are by far the largest portion, with $32 \%$. Meanwhile, credit unions, leasing and insurance assets combined have only a $4 \%$ slice of $\mathrm{GDP}^{2}$.

By the beginning of 2003, 10 licensed banks and four foreign bank branches were operating in Lithuania, as well as two foreign banks having representative offices. Total assets were LTL 17,2 billion ${ }^{3}$; individual or private household deposits were LTL 6,9 billion. The audited profit of the sector in 2002 amounted to LTL 146,8

\footnotetext{
* Dalia Šiukštiené - Lecturer of the Political Science Department of the Lithuanian Military Academy. Address: Šilo 5a, LT-10322 Vilnius, tel. +370-5-210 3570, e-mail: d.siukstiene@delfi.lt

1 "Finansų sektoriaus plètra iki 2015 metų", projektas, darbo grupès vadovè E.Martinaityté, Vilnius, 2002, http://www.ekm.lt/catalogs/33/strategijos/finansu sektorius.doc.

${ }^{2}$ Ibid.

${ }^{3}$ Kredito įstaigu veikla 2002 metais [Operations of Credit Institutions in 2002], LB, 200301 28, http://www.lbank.lt/istaigos/veikla2002a.htm
} 
million, which was the highest since independence 4 . In 2002, losses were reported by three banks, compared to six in 2001. Although there were opinions that re-pegging the litas from the US dollar to the Euro would cause inertia and ambivalence among individuals and corporations, that prediction did not prove correct. The European Commission experts filed a favourable report on the principal bank supervision authority, the Bank of Lithuania, while the World Bank Financial Sector Evaluation Program report concluded that the country has built a well functioning, secure and reliable banking system (...), and has a sound system of credit institutions' supervision, in line with international practice and EU requirements ${ }^{5}$. Yet, at the beginning of 2003, against a background of declared achievement and appraisal, Mečys Laurinkus, Director General of the National Security Department (NSD), issued an alarming comment on rumours about a new banking crisis: "(...) it is the opinion of the NSD that a rumour about a crisis within the largest Lithuanian bank is a menace to national security. (...) The rumour, to some extent, originated within the bank, then spread among certain competitors, and compiled into a complex; and eventually the head of the bank could only have mitigated it with a statement. Since no statement was made (in time), other national authorities and

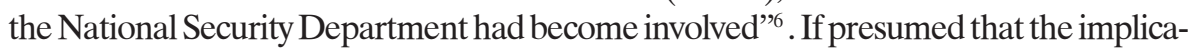
tion of such a statement leads us to the Lithuanian National Security Strategy ${ }^{7}$, whereby economic security is closely related to key national interests, this very fact implies a danger and a threat to the welfare of the population. It becomes a menace, when "shadowy financial and organized criminal groups act to become a threat to the state and the community"s.

The response of the market to the rumour of financial difficulties within the banking sector was immediate and resulted in the withdrawal of deposits: in December and January, Vilniaus Bankas customers (individuals and corporations) withdrew about LTL 0,6 billion. During December, time deposits fell by 1.5 per cent ${ }^{9}$, after continuous growth during the previous five-year period at an annual rate of LTL 800 million. It is evident that public trust in national financial institutions as guarantors of personal economic security determines the overall dominating attitude of market participants, thus becoming either a principal strength or weakness, either enhancing or inhibiting change. Individual attitudes and values shape the landscape for change, and the social and psychological context of change.

Lithuanian banks are now adding quite a number of modern services, including long-term deposits and investment management. They have also added new IT systems and banking technologies. The prerequisite for development is the presence of three key elements: the competence and reputation of the financial institutions' staffs, regulations, and effective supervision. Regrettably, regular public opinion polls by Vilmorus show that rumours about bank problems at the end of 2002 pushed the

${ }^{4}$ Ibid.

5 Ibid.

6 "From Rumour to Scandal", ELTA Information Agency, Lietuvos rytas, 200302 19, No. 41.

7 Lietuvos Respublikos Seimo nutarimas "Dèl Nacionalinio saugumo strategijos patvirtinimo", 2002 m. gegužès 28 d. Nr. IX - 907, Valstybès žinios, 200206 07, Nr. 56, 29.

${ }^{8}$ Ibid.

${ }^{9}$ Mantas Dubauskas, "Gandų kaina - apie pusę milijardo litų "[The price for rumor - half a billion litas], Lietuvos rytas, 200303 06, No. 54.

${ }^{10}$ „Do you trust these Lithuanian institutions ?“, Lietuvos rytas, 20032 12, No. 35. 
public trust from $32.7 \%$ down to $30.1 \%{ }^{10}$ within one month. Although the 2002 National Security Report admits that "The Lithuanian banking sector is very concentrated and depends on one foreign banking region, thus Nordic financial market problems may influence Lithuanian banking stability" 11 now that privately owned institutions are fighting for the new "meal" - national social insurance funds to be managed by the private pension funds ${ }^{12}$. It is evident that Scandinavian-controlled funds, employing very aggressive measures through expensive marketing tricks and experienced bank employees will consume the largest share. Eventually, tricky pension fund rules ${ }^{13}$, the current level of pensions unbalanced to long-term social insurance contributions, and quite improper marketing actions of competing fund managers to boot, bring about a variety of insinuations during TV discussions and in the press. This leads to the conclusion that the Lithuanian banking system, perceived by the population as an important criterion of economic safety (although considered safe and effective by experts and institutions), has not been positively perceived by its financial services' customers.

\title{
1. The Place of Banking within Security in General as Perceived on the Systemic and the Individual Level
}

\author{
It seems that the electorate votes \\ for their purses in support for the legislation that would \\ serve their private interest \\ George Soros ${ }^{14}$ :
}

The Government of the Republic of Lithuania, reporting to the Seimas and the society as a whole, praises its achievements in national security and lists a number of economic security factors: guarantees for the stability of fiscal and monetary policy; state debt management; development of a competitive economy and the energy sector; as well as its improvements in the supply and transportation infrastructure ${ }^{15}$. Theory suggests that security "from any objective point of view is estimated via the absence of threat to existing values, and on the subjective level it is absence of fear that

${ }^{11}$ Lietuvos Respublikos Seimas, 2002 metų nacionalinio saugumo sistemos būklès ir plètros ataskaita, 2003, http://www3.lrs.lt//pls/inter/w3_viewer.viewdoc?p_int_tekst_id.

${ }^{12}$ Lietuvos Respublikos Pensijų sistemos reformos įstatymas, 2002 m. gruodžio 3 d. Nr. IX-1215, Valstybès žinios, 2002, Nr. 123-5511.

${ }^{13}$ Lietuvos Respublikos Pensiju fondu istatymo pakeitimo istatymas, $2003 \mathrm{~m}$. liepos 4 d. Nr. IX1692, Valstybès žinios, 2003, Nr. 38-1672.

${ }^{14}$ George Soros. Pasaulinio kapitalizmo krizè: Atviroji visuomenè pavojuje [The Crisis of Global

Capitalism: Open Society Endangered], Vilnius: Tyto alba, 1999, 23.

${ }^{15}$ Seimas (cit. 11).

${ }^{16}$ Barry Buzan. Žmonès, valstybès ir baimè: tarptautinio saugumo studijos po šaltojo karo [ People, States and Fear: An Agenda for International Security Studies in the Post-Cold War Era], Vilnius:

Eugrimas, 1997, 50. 
the values shall be attacked"16. The author is not in pursuit of a wider definition of security, but presumes, agreeing with Barry Buzan, that the feeling of security is subjective, or, "credulousness does not necessarily imply real security" 17 , while the "idea that economic security is an absolute value that might be widely applicable, is just an illusion pursued by a hunter of Chimera" 18 . The reality of economic security is changeably and relatively linked with a number of contradictions and compromises either in the global finance arena, or national ambition to control capital and its movement, or the interest group level. For these reasons, this article will only stick to the combination of necessities that guarantee an "access to principal human needs (food, water, dwelling, education, etc)"19.

It is impossible to satisfy these needs in an organised society if there is no access to money and its management, i.e. without a functioning banking system. White paper, 1995 EC programme, addressing Central and East European countries accession to the $\mathrm{EU}$, lays out the fundamentals and stresses the financial sector as one of the principal actors in the economies - a channel for private savings and other financial capital to flow into investments, becoming a stimulating instrument of co-ordinated economic development for different sectors where capital can be used to the best advantage. If a well-functioning financial sector should be built on three elements - competence and reputation of the staff, relevant regulations and effective supervision - then, as the above mentioned EU document insists, it is even more important to achieve "full trust of financial market participants, both national and international" ${ }^{20}$.

Theoretical studies analyse systemic risks, or structural threats, that arise from the "shift of powers on the global financial markets - government (and international institutions) against markets, or public against public powers", when none of the financial institutions agree to comply with stricter standards than practised by competitors $^{21}$. Although Lithuania, in response to 1998 agreements with the IMF and the $\mathrm{WB}$, takes all precautions working towards effective international supervision standards and the transparency of financial information to prevent deep financial crises in the region, it does not mean (while bearing in mind theoretical assumptions) that governments are able to effectively control financial markets, or reinstall effective control of capital after the elimination of such control $^{22}$. The Lithuanian banking sector gets high national security grades on the background of other achievements, such as "low probability of banking threats, but bank management and regulation still to be improved due to the dynamic character of financial markets" ${ }^{\prime 2}$. A formal threat, or risk, is the presence of "Scandinavian investors, owning, through subsidiaries, $68,7 \%$ of the market" ${ }^{\prime 2}$. These banks' network expand over many countries and

\footnotetext{
${ }^{17}$ Ibid., 70.

${ }^{18}$ Ibid., 294.

${ }^{19}$ Ibid., 297.

${ }^{20}$ Lietuvos integracija ị Europos sajungą: bankininkyste ir finansai. Vilnius: Lietuvos bankas, 1997/

1,12 .

${ }^{21}$ Pauly, L., "Who Elected the Bankers?", New York: Cornell University Press (1997), 163.

${ }^{22}$ D. Held, A. McGrew, D. Goldblatt, J. Perraton. Globaliniai pokyčiai: politika, ekonomika ir kultūra

[Global Transformations Politics, Economies and Culture], Vilnius: Margi raštai, 2002, 243.

${ }^{23}$ Seimas (cit.11).

${ }^{24}$ Ibid.
} 
their ratings are not among the highest, thus the risk factor affects Lithuanian national security more than is officially acknowledged. Theoretically, we should accept that the global capital market does not exactly work "as a perfect integrated capital market (...), because borrowers and lenders have different opportunities to participate in this market" 25 . There exists settlement risk (threat): one time zone bank customer may "have met the obligations of the deal, while the other party is unable to pay the agreed amount at that time, and the liquidity risk - where parties to the deal are not able to pay the agreed amount" ${ }^{26}$. Presently, Lithuanian banking activities are supported by an interbank settlement system owned by the Bank of Lithuania, clearing every high or low value payment twice a day at fixed times. Integrating into the $\mathrm{EU}$, the current settlement system will have to be replaced by a real-time system, and join the TARGET. Deregulation of the national financial business in terms of services will become acute, when part of competencies have to be transferred into the hands of international supervisory institutions concentrating on unified security standards; the national guarantees will be important to those whose funds for international deals are held by banks. The funds held with the state deposit insurance fund are the principal guarantee today; the required minimum is regularly raised, but its influence on public opinion should not be overestimated. The deposit insurance fund reports that in 2002 its income was LTL 25 million, and the administrative costs stood at the level of 3.4\%. The fund held LTL 295 million $^{27}$, while bank deposits were LTL 11,7 billion. A simple calculation shows that only 1 of 40 litas of depositors' (both individual and corporate) funds are insured. Of course, reinsurance with foreign companies, liquidity of bank assets, fund management requirements, and state control measures to guarantee stability could be taken into account, but personally, arithmetic is more important.

Some researcher $\mathrm{s}^{28}$ offer to describe the concept of security on three levels: that of a state, an economic entity and a human being. National economic security is based on welfare, intellectual endeavours and cultural fields where the economic needs are to be satisfied. At this level, the principal problems and players appear from the economic policy or from within the national habitat ${ }^{29}$. The author will not go into details of security levels due to the limitations of this article. Taking as a given that the statement above is acceptable and in line with descriptive method ${ }^{30}$ in search of truth, the author will further estimate the relationship between the internal national environment and its actor-the human being-in the context of developing Lithuanian banking. This is demonstrated by a comment from the author's favourite economist: "in this world, (...) at the bottom of its economic theories and statistics, sunk well out of sight, are so many sweeping assumptions about people like you and me-about our needs and motivations and the purpose we have given our lives"'31. These thinking participants of economic and social affairs have the right to alter economic rules and social systems by simply expressing views on these systems ${ }^{32}$.

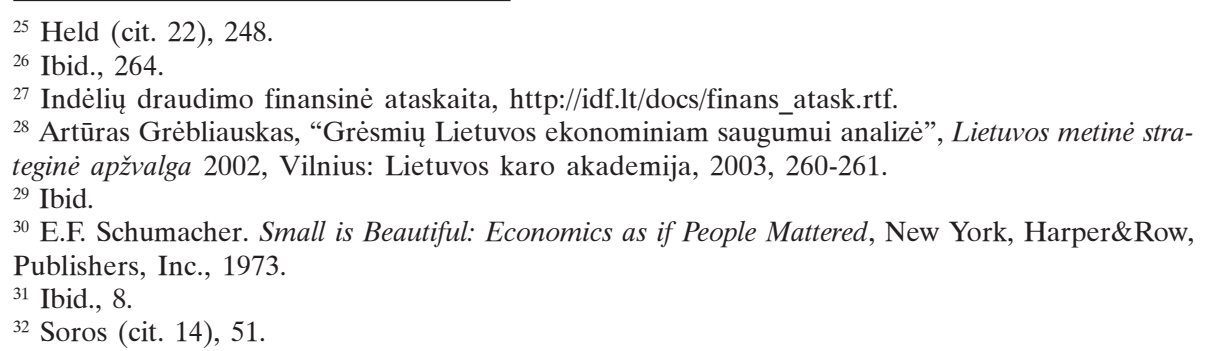


If applied to views on Lithuanian banking, it is worthwhile to look back at opinion polls by SIC, September - October 2001; respondents indicated their 4 most important qualities of a bank. They were (maximum rank is 51) ${ }^{33}$ :

No. Quality

1 Safety and reliability of bank, stability, reliable investors

Low bank fees

3 Convenience: easy to reach, many branches,

4

\section{ATMs, good location}

High-quality service and culture, reciprocity in customer relations

\section{Ranking}

18

This particular survey data allows us to conclude that due to past experiences and losses, 78\% of the population highly value safety and reliable bank investors. Quality of service and respect to customers is of topmost importance only to $35 \%$ of customers. To date, bank customers are users of only two main banking services: current and savings accounts, and payment cards ${ }^{34}$. The role of contemporary banking business in Lithuania is typically defined with clichés like: "It is O.K. to have such an institution, but it is not a matter of survival", "money depository", "a money depository that is safer than the purse or a stocking at home", "piggybank", "transmitter of wage or salary", "an intermediary between me and corporate finances; a possibility to spend as little as possible by using a payment card"35.

Should we agree that "behaviour, cognitive and motivational aspects of values disclose the socialisation process (experience) of an individual or group, are deeply rooted in the present, and are mirrored in the perception of current events the way they are related with the past human experience"36, and should we look back into the origins of Lithuanian banking with its regulatory base, into the reasons of domestic banking crises and the post-crises events, we will trace the connection between the individual experience and the attitude towards the current banking system, and personal economic safety, too.

${ }^{33}$ SIC, Naudojimosi bankinemis paslaugomis ịpročiai: kokybinio tyrimo ataskaita, 2001, spalis, SIC Rinkos tyrimai Brand Sellers DDB Vilnius užsakymu, 2001.

${ }^{34}$ Ibid., 13.

${ }^{35}$ Ibid., 22

${ }^{36}$ Irmina Matonyte, "Change of values of the elite in 1990-2000“, Artium Unitio, No 9, http:// www.artium.lt/9/elitas.html. 


\title{
2. The Battle of Economic Arguments and Ambition as Cornerstone of Lithuanian Banking
}

\author{
Market players do not start from knowledge. \\ They start by making a mistake \\ George Soros ${ }^{37}$
}

In 1988-1990, the national banking strategy was disputed, and restructuring methods were the main issue for competitors. Some experts advised an abrupt and swift "introduction" of a market economy, with a banking system suitable for the market economy of an independent country. Another research group insisted that, as long as no free market participants existed, the assets were state-owned, the market itself was disproportionate, foreign currency - the rouble - was in circulation, and the old credit system was still functioning, every restructuring measure should be taken step by step ${ }^{38}$. The Supreme Soviet, the then national legislature, on the wave of emotional upheaval, realised the need to find a solution when the Soviet banks' nationalisation draft was debated. In autumn 1990, Soviet banks in Lithuania were nationalised; although the regulation was emotionally motivated, it was not based on any analysis or banking practice in market economies. Nationalisation was meant to prevent the criminal use of national assets and the waste of funds. Following the resolution, the government and the Bank of Lithuania had to take over and incorporate into the central banking structure 4 Soviet banks and their assets. As a result, the authors of this resolution were severely criticised ${ }^{39}$.

Nevertheless, central bank management was not responsive to arguments and persuasion. Authorised to perform both central and commercial banking functions, it enjoyed political comfort and, as seen by economists and some politicians, was moving along the track of strategic and tactical mistakes. The availability of state financial resources managed by the central bank, from the very inception to be used for commercial purposes, was met with dissent from the new commercial banking community. The government did not interfere by merely stating that the bank should stand out and operate "ahead" of the economy, while the commercial banks shall perform classical roles, acting as intermediaries searching for trade partners abroad, being "accumulators" of information about resource and commodity markets, etc ${ }^{40}$.

Established in March 1990, the central bank management was preferably ignored by the commercial banking community and evidently not supported by the

\footnotetext{
${ }^{37}$ Soros (cit.14), 21.

${ }^{38}$ Linas Šadžius, "Du požiūriai ị Lietuvos bankininkystès kūrimą" [Two views on Lithuanian banking reform], http://ausis.gf.vu.lt/mg/98/1112/11bank.html.

${ }^{39}$ Ibid.

${ }^{40}$ Linas Šadžius, "Lietuvos šiuolaikinès bankininkyste raidos pradžia"[The beginning of the contemporary Lithuanian banking], http://ausis.gf.vu.lt/mg/98/1112/11bank.html.
} 
government. It was only in September 1990, when the Statute of the Bank of Lithuania was enacted, that the bank acquired its legal status with the exclusive power to license commercial banks, set the prudential requirements and ratios, and establish reporting regulations ${ }^{41}$. The supervisory function did not come until after the painful lessons of the 1995 Lithuanian banking crisis. Supervision had not existed for quite some time, for both objective and subjective reasons, and the concept of banking as a risk management business materialised after a decade of experience. It was only in 1997 that the Basle Committee and international accounting standards were introduced; traditional bank services ${ }^{42}$ replaced the profitable, but most risk-bearing, foreign exchange and high risk lending activities.

Commercial banks appeared uncontrolled, in abundance, and in an atmosphere of dispute. They came into existence as a result of the reorganisation of Soviet banks. In 1988, the Soviet Union state and specialised banks were granted the right to issue currency and distribute credit resources, while companies were allowed for the first time to hold accounts with any chosen bank. The State Bank no longer had a monopoly on managing corporate funds. 1988 was the year when the Soviet Law on Cooperation was enacted. It paved the road for the self-sustaining sectored and regional co-operative banks ${ }^{43}$ that first appeared in the cities of Russia, but also activated the market in Lithuania with new business ideas and offers. The independent Lithuanian government resolved to approve the December 1990 "initiative of Vilnius, Kaunas, Klaipėda, Šiauliai and Panevėžys companies to establish commercial banks" and register the institutions at the Bank of Lithuania ${ }^{44}$, and the idea of banking as a hot business materialised. Among the shareholders and pioneers were employees of state banks, municipalities, and governmental institutions. Those were the days when no land or real estate market existed; the legal system for lending, laws binding a loan to a mortgage, hypothecation were non-existent. Lack of legislation opened wide manipulative horizons for the stakeholders to use bank management for selfish purposes. The elected managerial staff came not from the professional community, but rather from the more aggressive businessmen and stakeholders.

The contemporary Lithuanian banking system appeared in a setting of idealism and financial power. As told by Juozas Nekrosius, one of the pioneers of commercial banking and head of the State Publishing and Printing Houses and Book Sales Affairs Committee by 1990: "Once, when I met Z. Zilevicius, the then head of the Bank of Lithuania, I inquired whether a private bank could be established. "Possible", he responded, "just send in the man who is interested"(...). The important thing is that we decided to have a bank not just for having a bank, our purpose was to transform the former committee into a modern concern" 45 .

As reported by the World Bank in 1988, the Bank of Lithuania legislative lag gave commercial banks the freedom to establish and develop as they wished. The

${ }^{41}$ Lietuvos Respublikos AT ir Vyriausybès žinios, 1990, Nr. 10, 374.

421998 metų pasaulio banko ataskaita: Lietuva/Bankininkystė, [World Bank Report], http:// www.lrv.lt/pasaul_bankas/Lithuania.php.

43 TSRS AT žinios. 1988, Nr. 22 (2460).

${ }^{44}$ Lietuvos Respublikos AT ir AT Prezidiumo dokumentu rinkinys. V., 1991, t.1, 621.

45 Vilniaus banko dešimtmetis: Prisiminimai ir dabartis. V.: AB Spauda, 2000, 14. 
supervisory function was in the grips of planned economy traditions and regulatory documents. It turned a blind eye to recommendations of Lithuanian economists and foreign consultants ${ }^{46}$. Ten years later, it was obvious that a central bank, busy with commercial functions, could not perform the role of an impartial guardian of the banking business and its incompetent, overambitious resolutions, exactly as some local economists and foreign advisers had forecasted, pushed the young banks to grapple with difficulties.

1990 to 1995 turned into a period of short-term loans. Commercial banks, often disregarding banking practice and foreign volunteer's advice and uncontrolled by the central bank, ignored credit risk and applied self-devised rules and requirements to loan applicants. Credits might have been granted within several days, unsecured, in millions, in cash, while the mortgage value or viability of a business plan was disregarded. Related or "important" clients enjoyed individual deposit interest rates which were sometimes twice as high as those offered to regular customers. Scrap metal, non-ferrous metals, petroleum products, cotton, milk powder, paper - all worth millions in Russia, Kazakhstan, and Uzbekistan, provided a bank's helping hand. The success of contracts depended not only on the reliability of the partner, but also on the political factors and criminal situation of the country where the goods originated. In 1993, bank loans to Lithuanian residents in litas were LTL 1,8 billion, in foreign currencies - LTL 1,4 billion; in 1994, 2,9 and 1,7 billion respectively ${ }^{47}$. Those were the years of colossal lending, comparable only to the larger "harvest" of $2002^{48}$. The 1993 litas loan rates stood at $64-108 \%$, foreign currency - at 53-73\%, and in 1994 respectively $47-74 \%$ and $42-64 \%{ }^{49}$. Loans were expensive but shortterm, agreements incorporated penalties for delayed repayment and, as described by experts, dragged businesses into insolvency throughout the period of 1990 to $1994^{50}$. Bad loans were accumulating, the Bank of Lithuania was not qualified to react, and 1995 expired with a moratorium on the biggest privately owned and 3 smaller banks with assets of one fourth of the total assets of the sector. The crisis left a painful imprint on the memory of the population: that of fear about investments and distrust in institutional banking are deeply rooted in the memories of those who experienced this crisis.

\footnotetext{
${ }^{46}$ World Bank (cit.42).

${ }^{47}$ Mènesinis biuletenis [Monthly Bulletin]. V.: Lietuvos bankas, 2003 Nr. 1, 29.

${ }^{48}$ Credit Institutions (cit.3).

${ }^{49}$ Bulletin (cit.47), 40.

${ }^{50}$ Maldeikis E., "Bankinès krizės pamokos ir dabartinè bankinio sektoriaus raida Lietuvoje" [Contemporary banking sector and lessons from banking crisis], http://finansai.tripod.com/bf.htm
} 


\title{
3. Behaviour and Attitudes of the Lithuanian Population on the Background of the Banking Crisis
}

\author{
There is no objective criterion to judge about values, \\ because they are not considered to match reality: \\ the criteria to judge about them are within
}

George Soros ${ }^{51}$

The first financial losses experienced by Lithuanians came as early as 1990 when the Soviet Vneshekonombank terminated its activities in Lithuania, keeping resident and corporate foreign currency funds in Moscow. Foreign currency accounts were held by some union-wide companies and residents receiving their salaries for work abroad (fishing and merchant fleet staff), legacy-holders or beneficiaries of overseas donations. In fact, Vneshekonombank was the only intermediary delivering foreign currency. The number of accountholders was not big, but when bank closure rumours spread, long queues lined up for days. The staff of the bank joined commercial banks and refused to "remember" their earlier job as well as the problems at Vneshekonombank. The silence still lingers in the air, especially regarding the losses of 1990, with the exception of a comment that the losses were not significant and that the issue will yet be raised in accordance with international law. Negotiations with the Russian authorities were to no avail, as was the investigation in Lithuania. In May 1999, The Lithuanian Commission For Economic Crime resolved that “(...) due to carelessness of the then head of the Bank of Lithuania, K. Ratkevičius, and bank management, no measures or actions were applied to suspend the funds of Vneshekonombank on the correspondent accounts with the Settlement Centre of the central bank, thereby the funds were misused and the Chairperson of the Liquidation Commission is responsible for the damage to the state of LTL 701500 " “52 .

Journalistic investigations concluded that the total loss amounted to USD 150 million, of which many millions were retrieved by companies, but not by individuals $^{53}$. On April 4th, 2003, on a national TV4 program "Korida", J.Lionginas, member of the Seimas and former Minister of Finance said that individual depositors of Vneshekonombank had already received 6 thousand litas each (the amount that was set as a compensation for depositors when litas were exchanged for the soviet rouble). He mentioned, too, that Moscow still owed USD 5 million and that any considerable compensation should not be expected.

Although the first experience of losses with Vneshekonombank were not significant for the welfare of the residents, stories about "something happening to some-

\footnotetext{
${ }^{51}$ Soros (cit. 14), 87.

52 "Dèl buvusios SSRS “Vnešekonombank" Lietuvos respublikinio banko (Ekonominiu ryšių su užsieniu banko) peremimo ir jo reorganizavimo tyrimo eigos, 199905 03", Seimo kronika:Komisijos, 1999 Nr.12 (117), 575

${ }_{53}$ Vyšniauskaitė B., "20 milijonų litu ịkalčiai saugomi Varènoje" [Evidence for 20 million litas have been kept in Varena], Ekstra, 200, Nr. 32 (95).
} 
body I know" were in circulation for quite some time. Fafo experts' survey on the living conditions in Lithuania in a Period of Transition (1996) concludes: "It comes as no surprise that confidence in the political system, as expressed though the people's trust in public authorities and figures, has dwindled. (...) there is a marked decrease in self-confidence and trust in own abilities, (...) people find themselves fighting the harsh realities of everyday life" ${ }^{4}$.

The qualitative survey of Lithuanian agency Baltic Surveys, "Lithuanian Population about Banks" 55 of December 1994 gives similar conclusions. The survey, based on RISC International methodology, reviewing detailed research of 1992, 1993 and 1994, says: "The majority of the population live as if they did not need banks. More than a half of adults have no relation to banks (...). Inflation expectations in Lithuania are high and typical of all population groups. No socio-demographic group trusts the stability of the litas. The majority among savers are those looking for security. Panic is a threat to personal security and is a sign of the erosion of safety." 56 Economic security in a RISC test of 1994 was the second most important value after "openness to the world", while "welfare status" stood at number 12, and "good health" was 27th; Estonian and Latvian residents, although they considered "openness to the world" the highest value, put economic security 4th, compared to 5th in UK, Spain, Italy, France and Germany. Thereby, identical surveys in these countries show that Lithuanians attached twice the importance to the values of "openness to the world and economic security“57.

The March-December 1994 survey by Baltijos tyrimai reflected the high trust Lithuanians vested in the state supervision, ignoring the shaping risk of this option.

Those who intended to save at banks ranked "high interest rates" (39\%) as most important, second was "good reputation" (38\%), and third - the "possibility to receive interest on a monthly basis" $(25 \%)^{58}$. Although opinion polls mirrored the high importance attached to economic security, they reflected respondents' financial incompetence, absence of risk awareness and a desire to profit as much as possible from savings. The authors of the survey issued a warning to the banking community: "It is worth mentioning that a similar case (bankruptcy) was observed in Poland, and "Sekunde" case resembles it. Necessary now is an immediate and clear response of mass media, and mobilisation of all financial and administrative reserves of the bank. It is topmost to advance rational behaviour of depositors" ${ }^{\prime 9}$. Regrettably, the information coming from Baltijos tyrimai was interesting to just a few banking professionals and did not receive wider public attention or incite any action.

High interest rates (the 1993 average litas deposit rate was 88,48\%, the foreign currency rate averaged $24,42 \%)^{60}$, as well as uncomplicated account opening and management procedures, enticed non-resident and foreign corporate funds into

\footnotetext{
${ }^{54}$ Knudsen K., Lithuania in a Period of Transition, Fafo Report 186, Forskningssiftelsen, 1996, 127

${ }^{55}$ Lietuvos gyventojai apie bankus: Tyrimo ataskaita, 1994 m. gruodis. V.: Baltijos tyrimai, 1994.

${ }^{56}$ Ibid, 3 .

${ }^{57}$ Ibid., 6.

${ }^{58}$ Ibid., 16

${ }^{59}$ Ibid., 2.

${ }^{60}$ Bulletin (cit.47), 37.
} 
Lithuanian commercial banks. At the close of 1993, non-resident deposits amounted to $4,3 \%$, while by the end of 1994 they increased to $14,2 \%{ }^{61}$. The US dollar was programmed to become a specific commodity in Lithuania since 1990, luring the population and companies to take advantage of exchange rate fluctuations and higher deposit rates. Confidence in the dollar had gone up prominently after the losses connected with the introduction of the litas, when a limit was set on the amount of roubles exchangeable to litas. Within one year, residents' deposits in foreign currencies increased by 2,8 times (from LTL 514,5 million on December 31st, 1993, to LTL 1471,6 million on December 31st, 1994) ${ }^{62}$.

Lithuanian treasury bills were first issued in 1994, and the issue amounted to LTL 563,33 million at an interest rate of $10,55 \%{ }^{63}$. The rate was not attractive for the population to invest in since it was just one fourth of the interest paid for deposits at commercial banks. $84,5 \%$ of investors into treasury bills were commercial and savings banks, with $11,5 \%$ of investors being non-residents ${ }^{64}$.

The population was saving, lending to banks and to pyramidal quasi-financial institutions, the so-called funds. Interest rates mounted to $100-200 \%$, make-do ads "we will convert you into millionaires" and the bank management demonstration of wealth - all was a decoy for investors. The authorities did not intervene or control the funds. After the first bankruptcies, the Bank of Lithuania refused to acknowledge any responsibility, since, it commented, the funds were not licensed by the bank. Nevertheless, prior to the bankruptcies, the population considered the funds state-controlled institutions. The populace, lacking a basic understanding of finance in general and not being provided adequate information, was a sincere believer in the ideology of the independent state with a competent and virtuous head of state. Over the period we are looking into, the state was perceived as a guarantor of economic security. The opportunity to employ one's funds and receive hot profit was imprinted in the cognition. E.F.Schumacher's idea that money is perceived as an almighty force explains the situation: it is generally believed that money can compensate the absence or loss of such values as justice, harmony, beauty or health, even if there is no possibility to buy these values for money ${ }^{65}$.

\footnotetext{
${ }^{61}$ Ibid.

${ }^{62}$ Ibid., 22.

${ }^{63}$ Lietuvos vyriausybès vertybiniu popieriu metine apžvalga, Lietuvos Respublikos finansų ministerija, 2002, http://www.finmin.lt.

${ }^{64}$ Ibid.

${ }^{65}$ Schumacher (cit. 30), 293.
} 


\title{
4. Reasons of Erroneous Banking in Lithuania: Politics, Macroeconomics and Mismanagement
}

\author{
Financial markets are distinctive (...): \\ their participants refuse any intrusion of the \\ government, but deep in the heart there is \\ hope that authorities will intervene \\ should the circumstances become harsh
}

George Soros ${ }^{66}$

Marketing books often give as an example of a banking crisis that which occurred in 1932, when an efficient US Last National Bank disregarded a rumour about its bankruptcy and was ruined within a few days; a number of other banks followed suit since the Federal Reserve was too late to intervene. The case is an example of how the rule of a selffulfilling prophecy ${ }^{67}$, attributed to Thomas Merton, works. The recommendation is to respond swiftly, using the skills of trained staff. At the start of 2003, the President of Vilniaus Bankas provided justification to the public: 'We have a policy of how to respond to war or emergency, but, as a matter of fact, we have no plan on how to behave in circumstances we have experienced recently ${ }^{368}$. It proves that neither global lessons nor failures experienced in Lithuania have been adequately assessed, while the motivation of decisions or behaviour preferences of the population are not considered important. In 2001, the Government of Lithuania, reporting on national security issues, stated that "the project of response to economic threats, guarantees of economic security and functioning of the economy was drawn in 2000 , but now, due to problems arising from "double coverage" of the program by other legal acts, the purpose of this project is questioned" ${ }^{\circ}$.

From the analytical point of view, it is generally accepted that instability in the banking sector would usually follow a serious change in the macroeconomic climate ${ }^{70}$. It refers to stable inflation, change of interest rates, foreign exchange fluctuations and other variables which are unpredictable by market participants. These were the principal causes of the first banking crisis in Lithuania. After five years of independent financial activity, the country was not different from any other post-planned-economy country, where financial market reform was launched from scratch: basic financial relations, rudimentary and hardly efficient, as well as a poor understanding of risk management, generated bad bank loans and vast internal corporate debts. A 1996 survey by Caprio and Klingebiel concludes that political factors, e.g. government interference and authority-imposed loans, were characteristic of one third of 29 systemic bank crises. Other variable factors were representative in half the crises, while mismanagement, poor bank supervision and careless licensing were typical for $60-80$ per cent of bank crises ${ }^{71}$.

\footnotetext{
${ }_{66}$ Soros (cit. 14),14.

${ }^{67}$ Ibid., 35.

${ }^{68}$ Dubauskas (cit. 9).

${ }^{69}$ Lietuvos Respublikos Seimas, 2001 metu nacionalinio saugumo sistemos būklès ir plètros ataskai-

ta, Vilnius, 2002, http://www3.lrs.lt/pls/inter/w3_viewer.viewdoc?p_int_tekst_id.

${ }^{70}$ Maldeikis (cit. 50).

${ }^{71}$ Ibid.
} 
Lithuanian banking regulation, characteristic of other, similar countries, was not analysed using local peculiarities. The emerging banking system had inherited (from a planned economy) poor efficiency and intensive government intervention into the sector via "facile loan extension". Business and capital was discouraged by voucher privatisation in 1992, when every individual received 5000 vouchers that actually fostered the accumulation of assets. The new entrepreneurs purchased vouchers to acquire assets on the cheap, but they were not oriented to competitive and efficient businesses. The preference was to obtain "hot" credit against non-profitbearing collateral. The loans were used to finance prestige consumption, additional privatization, or high-risk projects unrelated to the business activity reported to the bank. The voucher privatisation effect on the banking sector in Lithuania was devastating and propelled dead assets.

It was only in 1994 that the central bank introduced the required reserve ratio. It was the first sign of loss-awareness. The resolution induced a meltdown of bank profit. The required reserve ratio was lifted in 1995 and again in 1996, signalling deterioration of bank assets. Unaware of international accounting standards, management, shareholders and supervisors could not estimate the solvency and liquidity of banks. Supervisors, as a rule, did not find the alarming data useful, which should have served as a warning. More corrupt banks paid out enormous dividends from non-existent profits. The worst flaw was hidden in the taxation system because all fictitious bank profit was taxable ${ }^{72}$. Abuse by management, socially- and politicallyoriented lending raised the banking sector losses and reduced the profitability to the extent the there was insufficient profit to cover large operational costs.

When the 1995-1996 banking crisis is discussed, insolvency of two banks - Litimpeks and LAIB - is mentioned. These two suffered primarily due to large loans extended to the state-owned energy sector companies that were principal shareholders of these two banks. In 1994-1995, state-owned banks were on the verge of insolvency, too, and were latently bankrupt. It was only due to rigid supervision and support of the government that they could afford the demonstration of stability. The 1998 World Bank report concludes that the first banks to be closed were small, but in the summer of 1995, the population heard about problems in big banks. Depositors, including the government, began withdrawing funds from weaker banks, and by the end of 1995 a real crisis broke out (...). The government and the Bank of Lithuania were not able to resolve the crisis that embraced four banks, because such emergencies in the banking sector were not envisaged, bank regulation was ineffective while political involvement was ample ${ }^{73}$.

All Lithuanian banks were affected by the 1995-1996 crisis, and each was making an effort to solve its own crisis. Efficient solutions meant survival. Vilniaus Bankas was a specimen of a proficient solution. Its employees recall: "The rumour was about Vilniaus Bankas sinking, but we did not panic, because we had plenty of cash. We placed the cash packages at the cashiers' desks and were paying out money to every depositor wishing to withdraw"74 . Institutional measures applied with the

\footnotetext{
${ }^{72}$ A. Fleming, L. Chu and M.Bakker, "Banking Crisis in the Baltics", Finance and Development, March 1997.

${ }^{73}$ World Bank (cit. 42).

${ }^{74}$ Vilniaus Bankas (cit. 45), 17.
} 
first signs of the crisis helped more than the psychological. A bank manager remembers: "It was a coincidence that the Securities Commission registered a LTL 17 million issue of shares on "black Friday" - December 22, 1995, when tension was at its highest. Nomura International Plc (...), a London-based bank, subscribed to the newly-registered shares the same day and paid up on December 27'75.

A. Fleming, L.Chu and M. Bakker analysed the crises in all of the Baltic countries in 1997 and concluded that such crises are characteristic of transition countries. Governments should face them equipped with stronger supervision and resolute decisions. They concluded, too, that such crises pass fairly quickly, because depositors adjust to banks' unreliability. A survey of Vilniaus Bankas' customers (corporates and individuals) conducted by the author of this article February 15 to March 1, 1996 proved that argument. 230 corporate customers (about $20 \%$ of all active corporate account-holders, represented by top management) and 150 private individuals (about $5 \%$ of deposit-holders) expressed their views on the Lithuanian banking sector. The data, collected by the author of this article, lead to some important conclusions on the peculiarities of banking in Lithuania and on how economic security was perceived in those days.

Customer base analysis (February 15, 1996) indicated that $22 \%$ of Vilniaus Bankas customers were corporations who opened bank accounts after the operations of two commercial banks were suspended or those who opened accounts when regulations allowed them to hold more than one bank account. Thus, $68 \%$ of corporations had diversified their funds, mostly when the loss of funds risk was realised.

The majority of two bankrupt banks' customers, dissatisfied with a conservative VB credit policy, believed that the banking sector difficulties were temporary. The strict and formal VB requirements to applicants on providing financial information and necessary documents were unacceptable; respondents recollected the simplicity of operations and loan procedures at their former banks. Respondents were asked about their expectations related to foreign banks. 79\% stated that they anticipated foreign banks and motivated the expectations: "foreign banks don't lose customers' money", "loan terms and conditions are better", "they are better equipped and trust customers more". The survey leads to the conclusion that even after the first wave of bank crises in Lithuania, businesses had a peculiar understanding of the relationship between the bank and the customer: a commercial bank's mission was perceived as an easy and urgent financial response to business credit needs. The consequences of "hot lending" policy were not yet realised. Driven by the illusion of "hot business", corporate customers were not prioritising safety of funds held with banks, even after the operations of several banks were suspended.

The questionnaire for individuals targeted those who either extended their deposit agreements of did not withdraw funds from VB at the start of the crisis. Respondents described their deposits as:

$\begin{array}{ll}\text { All savings of the family } & 25.8 \% \\ \text { Part of family savings } & 22.6 \% \\ \text { Savings for the "lean days" } & 16.1 \% \\ \text { Money for consumer expenditure } & 12.9 \% \\ \text { Other answers } & 22.6 \%\end{array}$

${ }^{75}$ Ibid., 35 
Their answers may well illustrate the influence of the crisis on the welfare of the population, because in those days almost half of depositors placed either all or part of family savings with banks. When asked why, when crisis occurred, they did not panic and withdraw funds, we can judge that individual bank decisions were influencing customer beliefs, since more than 50\% trusted the bank and its staff. Other depositors were indifferent to the situation either because they were not reflecting on the banking situation or were lured by interest rates.

$80 \%$ of those who decided to withdraw their funds on the deposit maturity date motivated the withdrawal by "urgent need"; those who decided to extend their deposit agreements, explained:

$\begin{array}{ll}\text { Trust VB staff competence } & 80.0 \% \\ \text { Dangerous to keep money at home } & 50.0 \% \\ \text { Deposit with bank is not important business } & 35.0 \% \\ \text { Trust positive media comment on VB } & 20.0 \% \\ \text { Interest is means for daily existence } & 10.0 \% \\ \text { The state guarantees safety of deposit } & 10.0 \% \\ \text { No time to visit other banks } & 10.0 \% \\ \text { Trust friends' advice } & 10.0 \% \\ \text { Other answers } & 20.0 \%\end{array}$

The distribution of answers suggests that by successfully overcoming the crisis, VB managed to build strong customer trust in staff competence. Nevertheless, almost half remained indifferent to the bank's reliability factor. They either persistently believed in the state guarantees, friends' advice, media, or did not wish to attend to banking problems. The population, unlike corporate respondents indifferent to bank reliability, worded comments on the unreliability of the Lithuanian economic safety system as a whole:

"In Lithuania, one cannot trust anyone, but there's nothing else to do";

"I have doubts about banks, but one needs an account somewhere".

The survey leads to the conclusion supported by bank analysts that the 1995 banking crisis was regarded as a "necessary and unavoidable evil" by the population. The financial losses were not yet fully comprehended and responsibility for the decision-making was placed on the government. Several years later, a special Seimasnominated commission published the results of an investigation: “(...) Measures of the Government and the Bank of Lithuania, acts of officials may contain (...) negligence and abuse. Duly unattended to was the LAIB financial situation that caused its undue crisis, bank supervision, 1995 and 1996 ruined budgets, improperly provoked Litimpeks crisis, lack of preventive and control measures applicable to credit extension and bad debt collection" ${ }^{\prime \prime 6}$. Opinions of officials who were held responsible for the banking crisis were made public, too: "I know why such a scandalous path was taken. But I shall not disclose, for it is not my purpose (...) I do not understand why the authorities didn't find funds to save the banks, why they allowed to make lists of

${ }^{76}$ Vyšniauskaitė B., "Lietuvos bankų džiunglès ir gyventojai”[The jungle of Lithuanian banking and it's population], Ekstra, 1999 , Nr. 45 (58). 
depositors and let them queue through freezing nights at bankrupt banks to cause confusion and discontent with banks and the authorities" (comment by K. Ratkevičius, former governor of the Bank of Lithuania). "It was due to poor supervision by the Bank of Lithuania that Litimpeks and LAIB fell. LAIB had not been inspected for three years. If the bank was lending in dozens of millions and the debt was not serviced at maturity, could the Government or A.Šleževičius have anything to do about it? The nation was reciting my name, not K.Ratkevičius'; he was barely mentioned (comment by A.Šleževičius, former Prime Minister)" "77. The name of A. Šleževičius, and "the Šleževičius deposit story" is unforgettable to thousands as a reminder of the lessons of bank failure. The "story" is "about" a secretly withdrawn deposit: an advisor to the Prime Minister visited the bank with this purpose after the Bank of Lithuania suspended LAIB's operations in December 1995. A. Šleževičius' gain was LTL 135162 in cash, but not the regular LTL 6000 compensation in government securities afforded to all other depositors. In 2002, The Supreme Court of the Republic of Lithuania ruled that the operation was legitimate (Civil Code, 1964, Art. 434-445) ${ }^{78}$. Public opinion polls show that this fact is considered a case of social inequality and corruption, therefore the 2002 December rumour that "authorities have withdrawn funds from Vilniaus Bankas" was very close to becoming the cause of another banking crisis.

\title{
5. Anticipation of the "Self-fulfilling Prophecy" and Comprehension Economic Security
}

\author{
Rule-setting concerns group decisions, or politics. \\ Play by the rules concerns individual decisions, \\ or, in other words, behaviour in the market
}

George Soros 79

From the analytical point of view, contemporary Lithuanian banking is a milieu where "aggregate long-lasting consequences of activities of economic entities and governmental institutions in a way correspond to the concept of the institute as a social phenomenon" $"$. Some authors (T.Veblen, 1991) classify this as a dominating pattern of behaviour (habit) and conventional conception ${ }^{81}$. The "banking-in-crisis" situation and its solution had demonstrated the role of the authorities as "rule-setter" and "judge". According to Milton Friedman (1982), our pattern of behaviour is similar to players' behaviour on the playground. As a good game is a game where the players accept the rules and a referee is there to explain and to watch whether every-

\footnotetext{
77 Ibid.

${ }^{78}$ Lietuvos Aukščiausiasis Teismas: Nutartis Lietuvos Respublikos vardu, Civilinė byla Nr. 3K-7494/2002 m., 2002 m. kovo 28 d., Vilnius, http://www.lat.litlex.lt/Nutartys/cnut/htm.

${ }^{79}$ Soros (cit.14), 23.

${ }^{80}$ Lydeka Z., Rinkos ekonomikos tapsmas: Teoriniai svarstymai. K.: VDU leidykla, 2001, 76.

${ }^{81}$ Veblen T. The Place of Science in Modern Civilization and Other Essays, N.Y., 1991, 31.
} 
one plays by the rules; a good society needs agreement on common rules applied to behaviour, on measures applied in case of disagreement and on the mechanics to guarantee the observance of the common rules ${ }^{82}$.

The opinions of respondents about bankers and the motivation of behaviour are important criteria in terms of both organized activities and prevention of threats potentially undermining economic security. Lithuanian National Security Strategy does not present a definition of the national security concept, but some contemporary analysts interpret national security as the ability of the national state and its subjects to keep economic entities and systems in balance ${ }^{83}$. Public opinion polls ${ }^{84}$ indicate that even five years past the banking crisis, about 20 per cent of the population categorize the banking community as "deceivers, thieves and crooks", while more than 5 per cent saw a directly linked problem - lack of safety guarantees for deposit. Ordered by Lithuanian Banks Association, a survey conducted in 2000 confirmed that about two thirds of the population had not yet forgotten their experiences and were predicting new bank bankruptcies, i.e. the rule of the "self-fulfilling prophecy" was alive as a forewarning. Lithuanian National Security Strategy makes due provisions in terms of measures and means of economic security, including favorable investment and business climate. It also includes awareness and alertness of the whole economic infrastructure to react in case of emergencies or crises ${ }^{85}$. Therefore, it is reasonable to expect that institutions and executives would motivate their decisions not so much by theoretical definition, but more by evaluating factors influencing public attitudes towards personal economic security; these factors are still perceived as threats. Among the threats is general public (the aggregate of consumers of financial services) attitudes towards banking and investment that appears in the economic milieu and that is described as "aggregate short- and long-lasting consequences of natural processes as well as activities of economic entities and the regulating institutions" $"$.

Present-day attitudes of the population are predetermined by the flaws of banking system development, systemic and random mistakes and their consequences. In Banking Survey 2000, the distrust in the banking system causes could be judged from answers to two coded questions and respondents' wordings ${ }^{87}$ :

$$
\begin{aligned}
& \text { 1. } 35.2 \% \\
& \text { "peops of deposits: } \\
& \text { "criminals, guilty for depositors'losses, were not punished" } \\
& \text { "people were robbed, and they grouped together to steal" } \\
& \text { "because there were many people who were duped by banks" } \\
& \text { "the assets were taken away and losses never covered" } \\
& \text { "because I have suffered from Holding" } \\
& \text { "I have suffered from bank Sekunde, therefore I distrust all" }
\end{aligned}
$$

\footnotetext{
${ }_{82}$ Friedman M., Kapitalizmas ir laisvé [Capitalism and Freedom]. V.: Mintis, 1998, 32.

${ }^{83}$ Grébliauskas (cit.28), 262.

${ }^{84}$ Vilmorus, Nepasitikejimo komerciniais bankais priežastys: Reprezentatyvi gyventojų apklausa, 2000 m. balandžio 5-9 d., Lietuvos bankų asociacijos užsakymu. V.:Vilmorus, 2000.

${ }^{85}$ Lietuvos Respublikos Seimo nutarimas "Dèl Nacionalinio saugumo strategijos patvirtinimo", 2002 m. gegužès 28 d. Nr. IX - 907, Valstybès žinios, 200206 07, Nr. 56, 34.

${ }^{86}$ Lydeka (cit 80), 76.

${ }^{87}$ Vilmorus (cit.84), 14.
} 
2. Bankruptcies:

$34.1 \%$

"they have stolen everything and were bankrupt; no justice, only fraud and theft"

"when LDDP was in power(...), all money was lost, now nobody repays"

"what happened 10 years ago, will happen again"

"too many bankruptcies and bank fraud"

"they announce bankruptcy whenever they want"

"don't trust owners, and no insurance"

"if you lose money, the repayment is slow"

3. Cheat, thieve, swindlers $19.7 \%$

"bad reputation for long, all enriched themselves"

"no way to trust, these days you can't trust anyone"

4. Unreliable, unstable

$10.7 \%$

5. No guarantee of deposit security $\quad 5.2 \%$

6. Other $16.6 \%$

"present credit policy of banks is unreliable"

"the media informs that one cannot trust them"

"there are no real commercial banks in Lithuania"

"I have earned my money by honest work, so I do not

put them into untrustworthy hands"

"if you have reliable friends, then you can trust the bank"

"laws on deposit security are ineffective, weak economy and banks"

"obscure owners, audit material vague"

In 2002, all Lithuanian commercial banks, in compliance with the central bank Minimal Requirement on Disclosure of Public Information, started publishing core information on their financial situation, asset quality, compliance with bank exposure indicators, etc., on the websites. The Bank of Lithuania website informs the general public on a quarterly basis and presents indicators of the whole banking sector. This kind of competition has been driven by marketing and direct communication that promotes customer favour not only to a specific bank but to the whole banking system, too. This seems but a single honest way to determine the real attitudes of the population and react relevantly in pursuit of the long-term, albeit not easily gained, trust of depositors and investors. Videlicet, the competition among banks becomes healthy and informal, aimed at winning market participants' attention using their best efforts and meeting their expectations for "the rules of the game", which are customer-friendly and guarantee economic security. Otherwise, financial and business authors confirm that "not a single financial analyst has appeared to open a consultancy that would advise a customer. Blindly, intuitively and based on friends' advice more than on knowledge or professional recommendations we stumble between decisions on either depositing our savings with a bank, or investing into real estate, or life insurance" $" 88$.

\footnotetext{
${ }^{88}$ Redakcijos skiltis [Editorial], Verslo žinios, 200303 17, Nr. 453.
} 


\section{Conclusion}

Contemporary Lithuanian banking evolved from the Soviet era, when the restructuring of the system served to build the prerequisites for the flow of funds from state-owned to commercial banks. The Bank of Lithuania, as the supervisory institution, was established hastily, on the basis of a state bank, disregarding international practice or academic recommendations on economic restructuring. For quite a number of years, its operation was based on the principles of a planned economy, it was ignoring all advice from consultants about a market economy, it was blundering in strategic and tactical issues, and welcoming political decisions of the government.

Lack of experience, financial knowledge and a scarcity of information were the main causes of the public's confidence in the supervisory function of the authorities and the banking business. As a result, millions were lost. Five years from the inception of Lithuanian banking business, several banks were bankrupt, and the crisis had affected every single bank, all businesses and the population. From the analytical point of view, crises and financial losses are unavoidable in transition economies; they are transient, but result in depositors forming a perception of banks as unreliable. This perception, combined with the conclusion that there is a general public indifference to economic security, results in attitudes, at the personal level, being determined by confidential information and rumour.

Official information and statistics convince that banking in Lithuania has grown into a mature institutional system, capable of managing some of the market risks. Within ten years, accounting and reporting policies have been installed; effective supervision rules are now applied to banks working in different countries, but from different markets. Do we need another decade to erase from the memories the political and operational errors and financial losses? As noted by foreign experts ${ }^{89}$, neither exquisite buildings nor sophisticated banking equipment would help create the atmosphere for public trust. The real goal of everybody with any influence on banking - politicians, authorities, bank owners and managers - can only be achieved through high ethical standards and responsible behavior. Yet, it is regrettable that the disregard of legal norms; unpunished embezzlement and fraud; and examples of successful political or business careers of persons whose names are mentioned among those accused of financial losses do not promise a smooth passage towards favorable public opinion concerning the banking system as a guarantor of personal economic safety.

\footnotetext{
${ }^{89}$ Kai Kristoffersen, pranešimas konferencijai "Lietuva: dabartis ir perspektyvos" [Lithuania: present and prospects], Vilnius, 199909 23, http://erc.lt/Transition\%20conf/pranesimai-lt/santrka3.htm.
} 